\title{
Role of Eosinophilic Airway Inflammation in Models of Asthma
}

\author{
José R Lapa e Silva*/+, C Ruffié, J Lefort, M Pretolani, BB Vargaftig
}

Unité de Pharmacologie Cellulaire, Unité Associée Institut Pasteur/INSERM no. 285, Paris, France *Laboratório

Multidisciplinar de Pesquisa e Serviço de Pneumologia, Hospital Universitário Clementino Fraga Filho,

Universidade Federal do Rio de Janeiro and Laboratório de Pesquisa em Anatomia Patológica, Hospital Evandro

Chagas, Instituto Oswaldo Cruz, Av. Brasil 4365, 21045-900 Rio de Janeiro, RJ, Brasil

\begin{abstract}
Eosinophils play a central role in the establishment and outcome of bronchial inflammation in asthma. Animal models of allergy are useful to answer questions related to mechanisms of allergic inflammation. We have used models of sensitized and boosted guinea pigs to investigate the nature of bronchial inflammation in allergic conditions. These animals develop marked bronchial infiltration composed mainly of CD4+ T-lymphocytes and eosinophils. Further provocation with antigen leads to degranulation of eosinophils and ulceration of the bronchial mucosa. Eosinophils are the first cells to increase in numbers in the mucosa after antigen challenge and depend on the expression of $\alpha 4$ integrin to adhere to the vascular endothelium and transmigrate to the mucosa. Blockage of $\alpha 4$ integrin expression with specific antibody prevents not only the transmigration of eosinophils but also the development of bronchial hyperresponsiveness (BHR) to agonists in sensitized and challenged animals, clearly suggesting a role for this cell type in this altered functional state. Moreover, introduction of antibody against Major Basic Protein into the airways also prevents the development of BHR in similar model. BHR can also be suppressed by the use of FK506, an immunosuppressor that reduces in almost 100\% the infiltration of eosinophils into the bronchi of allergic animals. These data support the concept that eosinophil is the most important pro-inflammatory factor in bronchial inflammation associated with allergy.
\end{abstract}

Key words: eosinophil - $\alpha 4$ integrin - Major Basic Protein - FK506

ASTHMA AS AN INFLAMMATORY EOSINOPHILIC DISEASE

A silent revolution took place in the field of asthma pathogenesis over the last ten years. Until then, asthma was considered a disease caused mainly by bronchial smooth muscle disfunction (Kay 1991). Bronchial inflammation has been known as a feature of asthma for decades but it was always associated with terminal stages of the disease, and related to death caused by status asmaticus. Descriptions of severe bronchial infiltration by eosinophils and mononuclear cells, epithelial shedding, luminal plugs formed by exsudated proteins and inflammatory cells were tipically seen as hallmarks of terminal asthma (Dunnill 1960). Introduction of safe endoscopic procedures allowed physicians to examine the

This work was supported in part by grants from INSERM, Pasteur Institute, and by grants to JRLS from the Fundação Universitária José Bonifácio/FUJB and Brazilian Research Council/CNPq.

${ }^{+}$Corresponding author. Fax: +55-21-270.2193. E-mail: jrlapa@omega.lncc.br

Received 3 September 1997

Accepted 30 September 1997 bronchial mucosa of mild stable asthmatics, and some of the features seen in post-mortem examination were also present in this more benign form of asthma (Jeffery et al.1989, Azzawi et al. 1990). The flurry of information that followed these seminal observations firmly established asthma as an inflammatory disease. The recent definition proposed by the Global Initiative for Asthma stated that asthma is a chronic inflammatory disease with many cells contributing to its pathogenesis (NHLBI/WHO 1995). Eosinophils seem to play a key role in the establishment of bronchial inflammation in this condition, together with $\mathrm{T}$ lymphocytes that produce a set of cytokines typical of the Type 2 classification of Mossman and Coffman (Kay et al. 1991, Robinson et al. 1992). The presence of activated eosinophils, displaying positivity for the cleaved form of the eosinophil cationic protein (ECP) was correlated with bronchial hyperresponsiveness to metacholine. Eosinophilia was identified in all types of asthma, such as atopic, non-atopic, and occupational (Saetta et al. 1992). The possible role of eosinophils in asthma pathogenesis led to the development of diagnostic tools, such as the measurement of ECP in serum, bronchoalveolar lavage fluid or sputum of asthmatic patients, that can also be used as markers of 
disease progression or severity (Virchow et al. 1992). However, the evidences for the actual role of eosinophils in many aspects of asthma remain circumstantial. A mechanistic approach to answer these standing questions demands the use of animal models of allergy.

\section{CONTRIBUTION OF ANIMAL MODELS TO ESTAB- LISH CAUSALITY IN ALLERGIC INFLAMMATION}

The booster injection of antigen in sensitized guinea pigs leads to bronchial eosinophilia - We have used an animal model to investigate the establishment of bronchial allergic inflammation. Sensitization of guinea pigs with ovalbumin, followed by a booster injection of antigen two weeks later induced a marked bronchial inflammation characterized by the presence of increased numbers of eosinophils and CD4+ T lymphocytes (Lapa e Silva et al. 1992, 1993a). These events were temporally associated with enhanced bronchoconstriction to PAF and other agonists, and with release of secondary mediators in the effluent of the isolated perfused lungs (Pretolani et al. 1988).

Antigen challenge in boosted animals further increases bronchial eosinophilia and results in extensive epithelial shedding - Sensitized and boosted animals were further challenged with ovalbumin after protection with anti-histaminic and $24 \mathrm{hr}$ after the provocation a further increase in eosinophil numbers infiltrating the bronchial mucosa was seen, together with staining of extracellular granular material suggestive of eosinophil degranulation. Marked mucosal ulceration and epithelial shedding were noted in most animals of this group (Lapa e Silva et al. 1993b).

Antigen challenge in boosted animals results in infiltration of the bronchial mucosa by dendritic cells - Animals provoked as above had their bronchial mucosa infiltrated $24 \mathrm{hr}$ after challenge by cells with slender processes that stained very positive with a MHC Class II marker but failed to exhibit positivity for macrophages markers, thus suggesting that they were true dendritic cells (Lapa e Silva et al. 1994). The presence of increased numbers of dendritic cells in the bronchial mucosa could indicate persistence of the immune response by continuing antigen-presentation to T cells.

Adhesion of VLA-4+ cells to vascular endothelium is a rapid event after antigen challenge and precedes bronchial inflammation - Guinea pigs sensitized by repeated ovalbumin inhalation were killed at 3, 6, 24, and $72 \mathrm{hr}$ after the challenge. Sections were stained with the monoclonal antibody HP1/2 against the $\alpha 4$ chain of the integrin VLA-4. Positive cells adhering to the vascular endothelium of bronchial vessels were maximal at the first time point and remained high $6 \mathrm{hr}$ after antigen challenge but failed to show differences at later time points (Lapa e Silva, unpublished observations).

Eosinophils are the first inflammatory cell type to increase in bronchial mucosa after challenge and remain high at all time points - Using the above model, we examined the nature of bronchial inflammation at the same time points. Eosinophil numbers were significantly higher than controls 3 $\mathrm{hr}$ after challenge and remained higher at all time points examined, whereas CD4+ cells were only higher than controls $24 \mathrm{hr}$ after challenge (Lapa e Silva et al. 1995a).

\section{USE OF IMMUNOLOGIC TOOLS TO INVESTIGATE CAUSALITY IN ALLERGIC INFLAMMATION}

Antibody against $\alpha 4$ integrin prevents the development of eosinophilic bronchitis without affecting systemic eosinophilia - We used the monoclonal antibody HP1/2 as a tool to investigate the role of $\alpha 4$ integrins in the development of eosinophilic inflammation. Guinea pigs were sensitized by repeated inhalations of ovalbumin and provoked by the same route 14 days later and HP1/2 antibody was injected intravenously $1 \mathrm{hr}$ before and $4 \mathrm{hr}$ after antigen challenge. The monoclonal antibody totally prevented eosinophilia in the bronchoalveolar lavage (BAL) fluid and markedly inhibited the rise of eosinophil peroxidase levels in the BAL fluid of treated animals, suggesting that neutralization of $\alpha 4$ integrin prevented not only the homing of eosinophils to the airways but also their degranulation (Pretolani et al. 1994). Treatment with HP1/ 2 entirely prevented mucosal infiltration by eosinophils and CD4+ T cells. Blood eosinophilia was selectively increased by the $\alpha 4$ integrin treatment, indicating that inhibition of eosinophil recruitment to the alveolar compartment may partially account for their accumulation in the circulation (Pretolani et al. 1994).

Antibody against $\alpha 4$ integrin blocks the development of bronchial hyperreactivity - The effects described above were also accompanied by a marked reduction in the bronchoconstrictor response to intravenous methacholine in animals treated with the anti- $\alpha 4$ integrin antibody, in comparison with those treated with the corresponding isotype (Pretolani et al. 1994).

Antibody against eosinophil major basic protein $(M B P)$ prevents the development of bronchial hyperreactivity without affecting bronchial inflammation - Guinea pigs were sensitized as above and purified rabbit anti-guinea pig MBP antibody was injected intranasally $1 \mathrm{hr}$ before and $5 \mathrm{hr}$ after ovalbumin inhalation. Both BAL eosinophilia and in- 
filtration of the bronchial mucosa by eosinophils were unaffected by antibody treatment, remaining similar to those seen in isotype-treated provoked animals. Bronchial hyperreactivity to acetylcholine, however, was markedly reduced in animals treated with the anti-MBP antibody, strongly suggesting a central role for this cationic protein in the development of altered functional states in allergic inflammation (Lefort et al. 1996).

\section{USE OF PHARMACOLOGIC TOOLS TO MODULATE ALLERGIC INFLAMMATION}

Glucocorticosteroids but not nedocromil sodium decreases eosinophilic bronchitis - The effects of two standard anti-inflammatory drugs on the bronchial wall infiltration by eosinophils and other cell types were investigated using a guinea pig model. Animals were sensitized and boosted with ovalbumin and treated for five days after the booster injection of antigen with subcutaneous injection of either dexamethasone or nedocromil sodium. Bronchial infiltration by eosinophils and CD4+ cells was totally prevented by dexamethasone. Nedocromil sodium, however, failed to inhibit the eosinophilic bronchitis that accompanied the booster injection (Lapa e Silva et al. 1995b).

FK506 markedly reduces bronchial inflammation - The novel immunosuppressive drug FK506 was used in an animal model of allergic inflammation to investigate its effects on the bronchial mucosa. Guinea pigs were sensitized and boosted with ovalbumin and treated for five days by subcutaneous injections of FK506 from the day of the booster injection. The drug totally prevented the development of bronchial infiltration by eosinophils and CD4+ T cells (Lapa e Silva et al. 1995b).

FK506 blocks the development of bronchial hyperreactivity - We investigated the effects of FK506 on $\alpha 4$ integrin expression by inflammatory cells infiltrating the bronchi and on the emergence of bronchial hyperresponsiveness to acetylcholine. Guinea pigs received aerosol of avalbumin at days 0,2 , and were challenged at day 14. FK506 was administered $1 \mathrm{hr}$ before and $5 \mathrm{hr}$ after challenge. Treatment by the immunosuppressant was accompanied by a marked decrease in numbers of CD4+ cells and eosinophils in the bronchial mucosa. FK506 also reversed the increase in $\alpha 4$ integrin positive cells adhering to the vascular endothelium and infiltrating the bronchial mucosa. We found preliminary evidence that the drug also prevented the development of bronchial hyperesponsiveness to acethylcholine, possibly through its action on cell recruitment to the bronchial mucosa. One possible mechanism for this action is down-regulation of $\alpha 4$ integrin expression on inflammatory cells (Lapa e Silva et al. 1996).

\section{CONCLUDING REMARKS}

Data collected from studies with animal models of allergic inflammation establish a firm link between eosinophils and the development of pathologic changes in the bronchial mucosa, as well as with the accompanying functional state of hyperresponsiveness to agonists. Control of eosinophilia and of its causes are thus essential for a rational therapeutic approach in allergic inflammation.

\section{ACKNOWLEDGEMENTS}

To Mrs Cesonia Martinusso for expert technical help, to the students Alessandra Fonseca, Aline L do Amor Divino, Bianca B Torres, Flávia B Costa e Ivone O Morgado for collaboration during the studies, and to the student John Harrington III for reviewing the manuscript.

\section{REFERENCES}

Azzawi M, Bradley B, Jeffery PK, Frew AJ, Wardlaw AJ, Knowles G, Assoufi B, Collins JV, Durham S, Kay AB 1990. Identification of activated Tymphocytes and eosinophils in bronchial biopsies in stable atopic asthmatics. Am Rev Respir Dis 142: 14071413.

Dunnill MS1960. The pathology of asthma, with special references to changes in the bronchial mucosa. $J$ Clin Pathol 13: 27-38.

Jeffery PK, Wardlaw AJ, Nelson FC, Collins JV, Kay AB 1989. Bronchial biopsies in asthma. An ultrastructural, quantitative study and correlation with hyperreactivity. Am Rev Respir Dis 140: 1745-1753.

Kay AB 1991. Asthma and inflammation. J Allergy Clin Immunol 87: 893-910.

Kay AB, Ying S, Varney V, Gaga M, Durham SR, Moqbel R, Wardlaw AJ, Hamid Q 1991. Messenger RNA expression of the cytokine gene cluster, interleukin-3 (IL-3), IL-4, IL-5, and GM-CSF, in allergen-induced late-phase cutaneous reactions in atopic asthmatics. J Exp Med 173: 775-778.

Lapa e Silva JR, Pretolani M, Bachelet CM, Baker D, Scheper RJ, Vargaftig BB 1992. Booster-dependent alterations of the subsets of T-lymphocytes and eosinophils in the bronchi of immunized guinea pigs. Int Arch Allergy Immunol 99: 350-353.

Lapa e Silva JR, Pretolani M, Bachelet CM, Baker D, Scheper RJ, Vargaftig BB 1993a. Immunohistochemical characterization of T-lymphocytes and eosinophils in the bronchial wall of actively sensitized guinea pigs. Chest 103 (suppl.): 130-132.

Lapa e Silva JR, Pretolani M, Bachelet CM, Baker D, Scheper RJ, Vargaftig BB 1994. Emergence of Tlymphocytes, eosinophils and dendritic cells in the bronchi of actively sensitized guinea pigs after antigenic challenge. Braz J Med Biol Res 27: 1653-1658.

Lapa e Silva JR, Ruffié C, Lefort J, Vargaftig BB, Pretolani M 1995a. Kinetics of antigen-induced changes in the airways of aerosol sensitized guinea pigs (abstract). Am J Respir Crit Care Med 151: A393

Lapa e Silva JR, Bachelet CM, Pretolani M, Baker D, Scheper RJ, Vargaftig BB 1993b. Immunopathologic 
alterations in the bronchi of immunized guinea pigs. Am J Respir Cell. Mol Biol 9: 44-53.

Lapa e Silva JR, Ruffié C, Vargaftig BB, Pretolani M 1995b. Modulation of the bronchial inflammation in sensitized guinea pigs by FK506, nedocromil sodium or dexamethasone. Eur Respir J 8: 1321-1327.

Lapa e Silva JR, Ruffié C, Vargaftig BB, Pretolani M 1996. FK506 down-regulates $\alpha-4$ ntegrin expression in the lungs of sensitized guinea pigs (abstract). Am J Respir Crit Care Med 153: A645.

Lefort J, Nahori MA, Ruffié C, Vargaftig BB, Pretolani M 1996. In vivo neutralization of eosinophil-derived major basic protein inhibits antigen-induced bronchial hyperreactivity in sensitized guinea pigs. J Clin Invest 97: 1117-1121.

NHLBI/WHO report 1995. Global initiative for asthma. Global strategy for asthma management and prevention. National Institutes of Health. Publication number 95-3659.

Pretolani M, Lefort J, Vargaftig BB 1988. Active immunization induces lung hyperresponsiveness in the guinea pig. Pharmacological modulation and triggering role of the booster injection. Am Rev Respir Dis 138: 1572-1578.

Pretolani M, Ruffié C, Lapa e Silva JR, Joseph D, Lobb RR, Vargaftig BB 1994. Antibody to very late activation antigen 4 prevents antigen-induced bronchial hyperreactivity and cellular infiltration in the guinea pig airways. J Exp Med 180: 795-805.

Robinson DS, Hamid Q, Ying S, Tsicopoulos A, Barkans J, Bentley AM, Corrigan C, Durham SR, Kay AB 1992. Predominant Th2-like bronchoalveolar T-lymphocyte population in atopic asthmatics. $N$ Eng $J$ Med 326: 298-304.

Saetta M, di Stefano A, Maestrelli P, de Marzo N, Milani GF, Pivirotto F, Mapp CE, Fabbri LM 1992. Airway mucosal inflammation in occupational asthma induced by toluene diisocyanate. Am Rev Respir Dis 145: 160-168.

Virchow, Jr JC, Hölscher U, Virchow, Sr C 1992. Sputum ECP levels correlate with parameters of airflow obstruction. Am Rev Respir Dis 146: 604-606. 